\title{
Effects of Ramosetron on Gastrointestinal Transit of Guinea Pig
}

\author{
Yoo Mi Park, ${ }^{1}$ Young Ju Lee, ${ }^{1}$ Young Ho Lee, ${ }^{2}$ Tae II Kim ${ }^{1}$ and Hyojin Park ${ }^{1 *}$ \\ Departments of ${ }^{1}$ Internal Medicine and ${ }^{2}$ Physiology, Yonsei University College of Medicine, Seoul, Korea
}

\section{Background/Aims}

A selective 5-hydroxytryptamine (5-HT) type 3 receptor antagonist, ramosetron, inhibits stress-induced abnormal defecation in animals and is currently used as a therapeutic drug for irritable bowel syndrome with diarrhea. The aim of this study is to investigate the effect of ramosetron on altered gastrointestinal (GI) transit.

\section{Methods}

Male guinea pigs weighing approximately $300 \mathrm{~g}$ were used. The effect of ramosetron was investigated on altered $\mathrm{Gl}$ transit induced by thyrotropin-releasing hormone (TRH), 5-HT, or mustard oil (MO). GI transit was evaluated by the migration of charcoal mixture from the pylorus to the most distal point, and expressed as a percentage $(\%)$ of charcoal migration $(\mathrm{cm})$ of the total length of total small intestine $(\mathrm{cm})$.

\section{Results}

The average charcoal transit was $51.3 \pm 20.1 \%$ in the control (vehicle) group, whereas in the ramosetron group charcoal moved $56.6 \pm 21.9 \%, 46.9 \pm 9.14 \%$ and $8.4 \pm 5.6 \%$ of the total small intestine at the concentrations of 10,30 and 100 $\mu \mathrm{g} / \mathrm{kg}$, respectively. Gl transit after administration of TRH $(100 \mu \mathrm{g} / \mathrm{kg}), 5-\mathrm{HT}(10 \mathrm{mg} / \mathrm{kg})$ or MO $(10 \mathrm{mg} / \mathrm{kg})$ was accelerated compared to vehicle (5-HT, $94.9 \pm 9.22 \%$; TRH, $73.4 \pm 14.7 \%$; MO, $81.0 \pm 13.7 \%)$. Ramosetron inhibited GI transit altered by $5-\mathrm{HT}$, TRH or MO.

\section{Conclusions}

Ramosetron modulated GI transit. We suggest that ramosetron may be therapeutically useful for those with accelerated upper Gl transit.

\section{(J Neurogastroenterol Motil 2013;19:36-41)}

\section{Key Words}

Gastrointestinal transit; Mustard oil; Ramosetron; Serotonin 5- $\mathrm{HT}_{3}$ receptor antagonist; Thyrotropin-releasing hormone

Received: October 17, 2012 Revised: November 30, 2012 Accepted: December 7, 2012

(c) This is an Open Access article distributed under the terms of the Creative Commons Attribution Non-Commercial License (http://creativecommons. org/licenses/by-nc/3.0) which permits unrestricted non-commercial use, distribution, and reproduction in any medium, provided the original work is properly cited.

*Correspondence: Hyojin Park, MD, PhD

Department of Internal Medicine, Gangnam Severance Hopsital, Yonsei University College of Medicine, 211, Eonju-ro, Gangnam-gu, Seoul 135-720, Korea

Tel: +82-2-2019-3318, Fax: +82-2-3463-3882, E-mail: hjpark21@yuhs.ac

Financial support: This study was supported in part by a research fund from Astellas Pharma, Inc., Korea.

Conflicts of interest: Yoo Mi Park and Hyojin Park planned this study. Yoo Mi Park and Young Ju Lee was conducted the study. Young Ho Lee and Tae II Kim contributed to revise and draft the manuscript. Yoo Mi Park wrote the paper. 


\section{Introduction}

As a potent and selective 5-hydroxytryptamine type 3 receptor antagonist $\left(5-\mathrm{HT}_{3} \mathrm{RA}\right)$, ramosetron hydrochloride (ramosetron), has been introduced in Japan to treat gastrointestinal (GI) symptoms such as nausea and vomiting caused by antineoplastic agents. ${ }^{1}$ 5-HT ${ }_{3} \mathrm{RAs}$ (e.g., ondansetron and granisetron) have been reported to inhibit GI motility and reduce visceral sensitivity. ${ }^{2,3}$ Ramosetron also has a long-acting inhibitory effect on stress-induced abnormal defecation in rats, though the drug does not influence normal defecation. ${ }^{4}$ Unlike existing antidiarrheal and spasmolytic agents, 5- $\mathrm{HT}_{3} \mathrm{RAs}$ work through inhibition of colonic hyperalgesia. ${ }^{5}$ Therefore, ramosetron is currently used as a therapeutic drug for irritable bowel syndrome with diarrhea (IBS-D). ${ }^{6,7}$ However, few studies have evaluated the effect of ramosetron on upper GI transit.

This study investigated the effects of ramosetron on GI transit with 5-HT, thyrotropin-releasing hormone (TRH) and mustard oil (MO). The latter two were selected as TRH enhances serotonin-induced GI motility, ${ }^{8,9}$ and as MO activates transient receptor potential ankyrin-1 (TRPA-1) to induce 5-HT release from enterochromaffin (EC) cells in vitro. ${ }^{10}$ Furthermore, our study verified the inhibitory effects of ramosetron on altered GI transit induced by 5-HT, TRH and MO in guinea pigs.

\section{Materials and Methods}

\section{Animals}

Adult male Hartley guinea pigs (250-350 g, Orient Bio, Inc., Seoul, Korea) were acclimated to their holding room (temperature controlled at $21 \pm 11^{\circ} \mathrm{C}, 50 \pm 10 \%$ humidity and 12-hour light/dark cycle). A standard guinea pig diet (7006; Teklad Guinea Pig Diet, Harlan Laboratories, Madison, WI, USA) and drinking water were provided ad libitum. Guinea pigs were deprived of food overnight before the experiment but were allowed free access to water. All experiments were conducted in accordance with the Guide for the Care and Use of Laboratory Animals provided by the Animal Laboratory Ethics Committees of the Department of Laboratory Animal Medicine, Medical Research Center, Yonsei University College of Medicine.

\section{Drugs and Chemicals}

The following drugs and chemicals were used: pentobarbital sodium (Hanlim Pharmaceuticals, Seoul, Korea), charcoal (Sigma, St. Louis, MO, USA), ramosetron hydrochloride (Astellas Pharma, Inc., Tokyo, Japan), 5-HT (Sigma), TRH (Sigma) and MO (Sigma). Ramosetron, 5-HT and MO were administrated orally with a charcoal mixture. For experiments involving TRH, this drug was mixed in saline and injected subcutaneously (SC) at total dose of $2 \mathrm{mg} / \mathrm{kg}$ prior to charcoal mixture administration.

\section{Experimental Design}

\section{Assessment of gastrointestinal transit}

After being fasted for 24 hours with free access to water, guinea pigs were anesthetized by intraperitoneal (i.p.) injection of pentobarbital sodium (40 mg/kg). GI transit was measured by using the charcoal transit assay. The charcoal mixture consisted of charcoal, barium and normal saline mixed in a 1:2:6 ratio. The guinea pigs received an intragastric administration of charcoal mixture combined with ramosetron, 5-HT and MO through orogastric cannula. TRH was injected SC. After 2 hours, the guinea pigs were sacrificed. The abdomens were opened and the intestines were removed from the pyloric junction to the ileocecal valve. GI transit was evaluated as the migration of charcoal mixture from the pylorus to the most distal point of migration and expressed as a percentage $(\%)$ of charcoal migration $(\mathrm{cm})$ through the total length of small intestine $(\mathrm{cm})$. The distance moved through the small intestine represents both gastric transit and small bowel transit. Additionally, small intestine transit is used interchangeably with upper GI transit. ${ }^{11}$

Effect of ramosetron, 5-hydroxytryptamine, thyrotropinreleasing hormone or mustard oil on gastrointestinal transit

Ramosetron (10, 30 and $100 \mu \mathrm{g} / \mathrm{kg}$ ) was administered via charcoal mixture through an orogastric cannula. Likewise, 5-HT $(1,5$ and $10 \mathrm{mg} / \mathrm{kg})$ and $\mathrm{MO}(0.1,1$ and $10 \mathrm{mg} / \mathrm{kg})$ were also administered by the same method. TRH (1, 10 and $100 \mu \mathrm{g} / \mathrm{kg}$ ) was administered SC. Unlike the 5-HT and MO group, which were given the drug per os, TRH group had its agent subcutaneously injected. To offset the effect due to the difference of administration, 2 control group was formed. Doses were selected based upon the results of preliminary experiments as well as on previously published data. ${ }^{12-15}$

Effect of ramosetron on altered gastrointestinal transit induced by 5-hydroxytrytamine, thyrotropin-releasing hormone or mustard oil

Ramosetron (10, 30 and $100 \mu \mathrm{g} / \mathrm{kg}$ ) was administered via 
charcoal mixture combined with 5 -HT $(10 \mathrm{mg} / \mathrm{kg})$ or MO (10 $\mathrm{mg} / \mathrm{kg})$ through an orogastric cannula. TRH (100 $\mu \mathrm{g} / \mathrm{kg})$ was concurrently administered via charcoal mixture combined with ramosetron $(10,30$ and $100 \mu \mathrm{g} / \mathrm{kg})$ through an orogastric cannula.

\section{Statistical Methods}

Different doses of the same treatment protocol were given at the same time-point to determine that the effects of drug treatment on charcoal transit were dose-dependent. The 'within group' multiple comparisons were assessed by one-way analysis of variance. The mean and standard deviation of the mean of charcoal transit rate for each treatment group were calculated. The student's $t$ test was used to compare individual treatment groups. A $P$-value of less than $0.05(P<0.05)$ was considered to be statistically significant. All data were analyzed using the SPSS version 17.0 for Windows software (SPSS Inc., Chicago, IL, USA).

\section{Results}

\section{Effect of Ramosetron on Gastrointestinal Transit}

The average charcoal transit was $51.3 \pm 20.1 \%$ in the control (vehicle) group $(\mathrm{n}=7)$ (Fig. 1). After oral administration of ramosetron, the transit was $56.6 \pm 21.9 \%(n=6), 46.9 \pm 9.1 \%(n$ $=6)$ and $8.4 \pm 5.6 \%(\mathrm{n}=6)$, at ramosetron doses of 10,30 and $100 \mu \mathrm{g} / \mathrm{kg}$, respectively $(P<0.01)$.

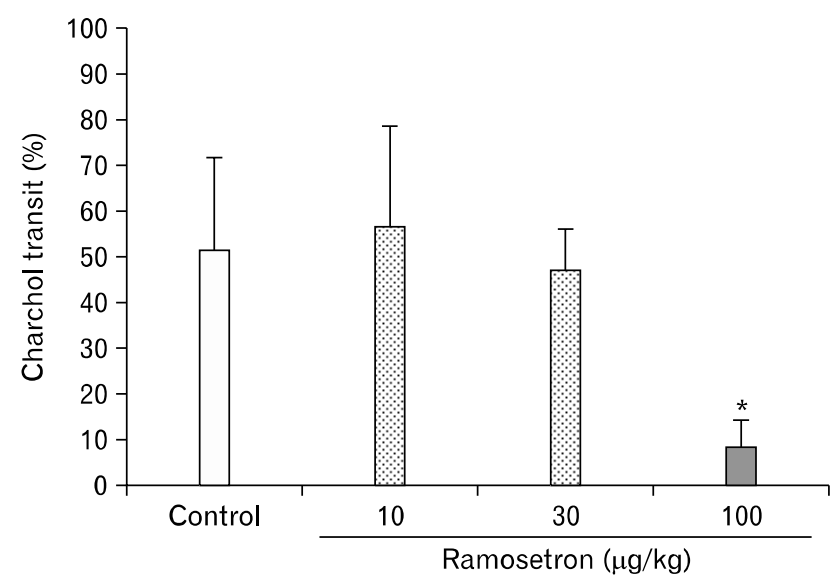

Figure 1. The effect of ramosetron on gastrointestinal (GI) transit. Ramosetron inhibits GI transit. ${ }^{*} P<0.01$ compared with the control group $(\mathrm{n}=7)$.

\section{Effect of 5-hydroxytryptamine, Thyrotropin-re- leasing Hormone or Mustard Oil on Gastro- intestinal Transit}

Oral administration of $5-\mathrm{HT}$ at doses of 1,5 and $10 \mathrm{mg} / \mathrm{kg}$ accelerated GI transit of charcoal in a dose-dependent fashion (Fig. 2). In the control group $(\mathrm{n}=7)$ the charcoal moved $51.3 \pm$ $20.1 \%$, whereas the transit for the $5-\mathrm{HT}$ group was $55.1 \pm$ $20.5 \%(n=6), 64.7 \pm 20.9 \%(n=6)$ and $94.9 \pm 9.2 \%(n=6)$ at doses of 1,5 and $10 \mathrm{mg} / \mathrm{kg}$, respectively. A significant change was observed at a 5 -HT dose of $10 \mathrm{mg} / \mathrm{kg}(P<0.01)$.

Similarly, subcutaneous administration of TRH accelerated charcoal transit (Fig. 3). The charcoal moved 56.1 $\pm 18.4 \%$ in the control group $(n=6)$, whereas for the TRH group the charcoal transit was $45.5 \pm 16.9 \%(\mathrm{n}=6), 52.1 \pm 17.4 \%(\mathrm{n}=6)$ and $73.5 \pm 14.7 \%(\mathrm{n}=6)$ at doses of 1,10 and $100 \mu \mathrm{g} / \mathrm{kg}$, respectively. The maximum effect was achieved for $\mathrm{TRH}$ at a dose of $100 \mu \mathrm{g} / \mathrm{kg}(P=0.102)$.

Oral administration of $\mathrm{MO}$ also accelerated GI transit (Fig. 4). In the control group $(\mathrm{n}=7)$ the charcoal moved $51.3 \pm 20.1 \%$, and in the MO group the charcoal transit was $33.9 \pm 15.3 \%(\mathrm{n}=$ $6), 61.3 \pm 9.8 \%(n=6)$ and $81.0 \pm 13.7 \%(n=6)$ at doses of 0.1 $(\mathrm{n}=6), 1$ and $10 \mathrm{mg} / \mathrm{kg}$, respectively. A significant difference was observed for $\mathrm{MO}$ at a dose of $10 \mathrm{mg} / \mathrm{kg}(P<0.01)$.

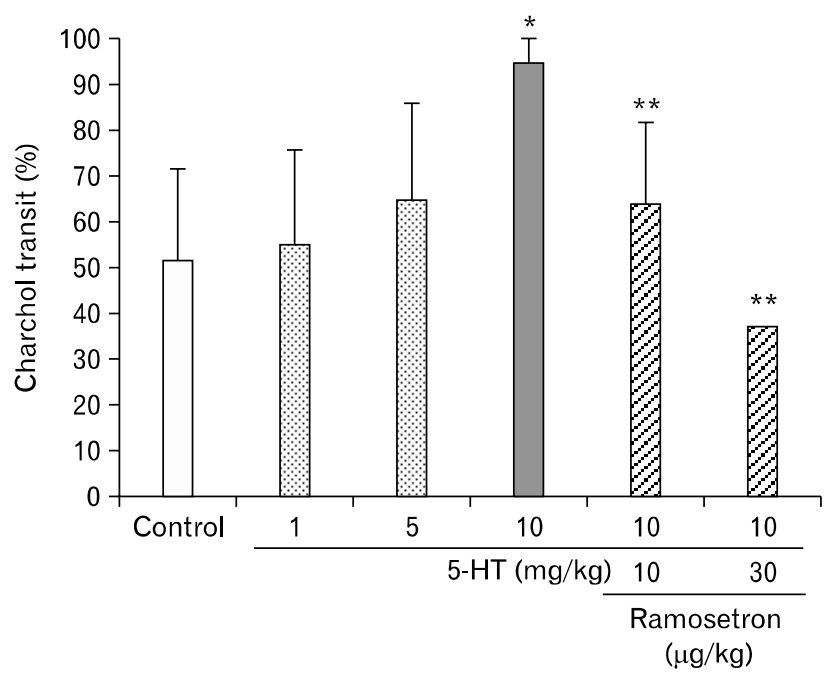

Figure 2. The effect of ramosetron on altered gastrointestinal (GI) transit induced by 5 -hydroxytryptamine $(5-\mathrm{HT})$. The 5 -HT accelerated GI charcoal transit dose-dependently. The maximum effect was observed at a dose of $10 \mathrm{mg} / \mathrm{kg}\left({ }^{*} P<0.01\right.$ compared with the control group $[\mathrm{n}=7])$. Ramosetron significantly inhibited the accelerated GI transit caused by $5-\mathrm{HT}\left({ }^{* *} \mathrm{P}<0.01\right.$ compared with the 5 -HT group [n $=6]$ ). 


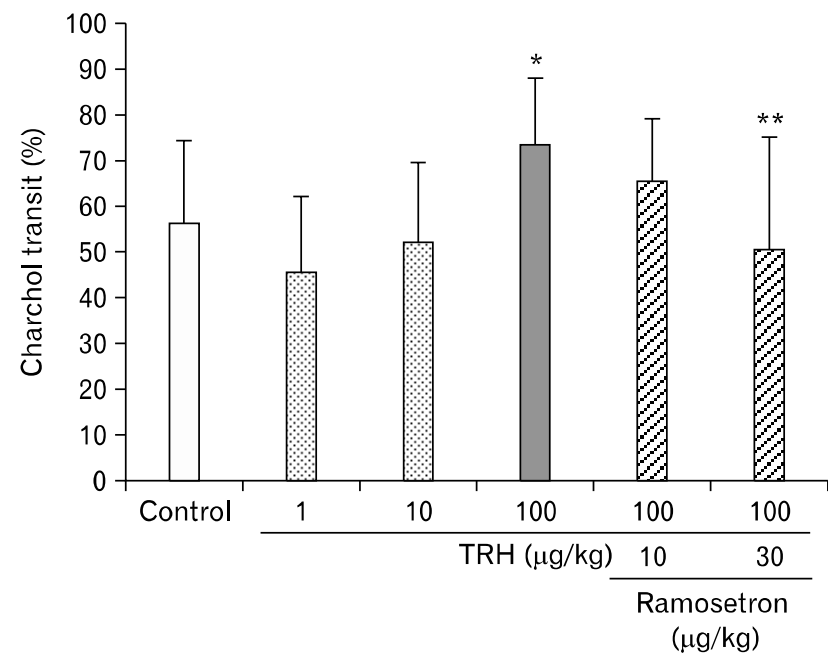

Figure 3. The effect of ramosetron on altered gastrointestinal (GI) transit induced by thyrotropin-releasing hormone (TRH). TRH accelerated GI charcoal transit. The maximum effect was observed in TRH at a dose of $100 \mu \mathrm{g} / \mathrm{kg}\left({ }^{*} P=0.102\right.$ compared with the control group $\left.[\mathrm{n}=6]\right)$. Ramosetron significantly inhibited the accelerated GI transit caused by $\mathrm{TRH}(* * P<0.05$ compared with the TRH group $[\mathrm{n}=6])$.

\section{Effect of Ramosetron on Altered Gastrointe- stinal Transit Induced by 5-hydroxytryptamine, Thyrotropin-releasing Hormone or Mustard Oil}

Oral administration of ramosetron at doses of 10 and $30 \mu \mathrm{g} / \mathrm{kg}$ inhibited 5-HT, TRH and MO-induced accelerated GI transit (Fig. 2-4). In particular, ramosetron at a dose of $30 \mu \mathrm{g} / \mathrm{kg}$ significantly inhibited the accelerated GI transit caused by 5-HT at a dose of 10 $\mathrm{mg} / \mathrm{kg}(P<0.01, \mathrm{n}=6)$, TRH at a dose of $100 \mu \mathrm{g} / \mathrm{kg}(P<0.01, \mathrm{n}$ $=6)$ and $\mathrm{MO}$ at a dose of $10 \mathrm{mg} / \mathrm{kg}(P<0.01, \mathrm{n}=7)$.

\section{Discussion}

Ramosetron, a selective $5-\mathrm{HT}_{3} \mathrm{RA}$, inhibits GI transit. This effect was well demonstrated by its inhibitory effects on accelerated GI transit caused by 5-HT, TRH and MO in this study.

The $5-\mathrm{HT}$ is an important signaling molecule that involves peristaltic, secretory, vagal and nociceptive reflexes. ${ }^{16}$ This signaling molecule is found in the GI tract in the interneurons that terminate in the myenteric and submucosal plexuses, ${ }^{17}$ is released from EC cells by vagus nerve stimulation, and induces a release of acetylcholine from excitatory (cholinergic) neurons. ${ }^{18} \mathrm{TRH}$ stimulates the centers of the brain which control the vagal-enteric nervous systems, and involves cholinergic and serotonergic mechanisms. ${ }^{19}$ The smooth muscle contraction that is elicited is influenced by changes of neurotransmitter release, either pos-

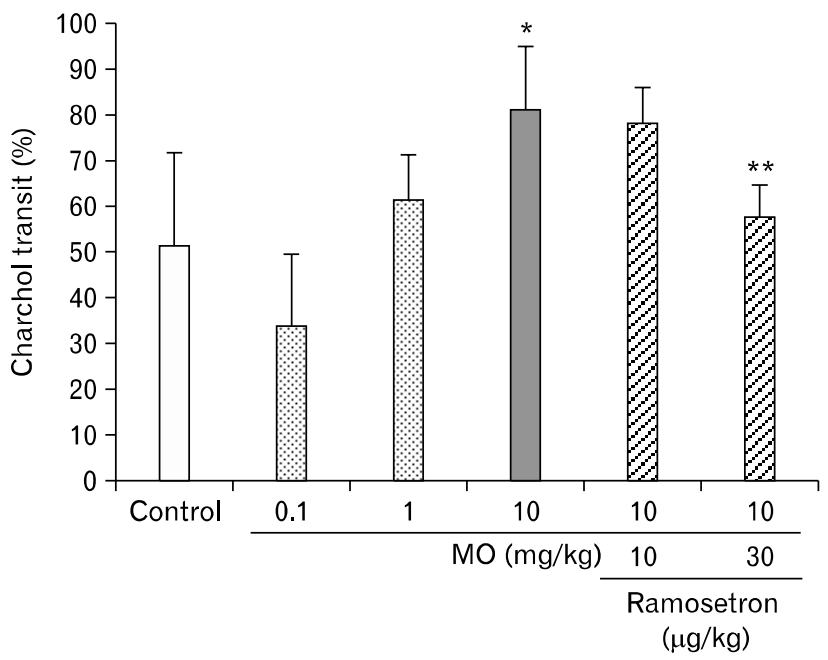

Figure 4. The effect of ramosetron on altered gastrointestinal (GI) transit induced by mustard oil (MO). MO accelerated GI charcoal transit. The maximum effect was observed in $\mathrm{MO}$ at a dose of $10 \mathrm{mg} / \mathrm{kg}$ $\left({ }^{*} P<0.01\right.$ compared with the control group $\left.[\mathrm{n}=7]\right)$. Ramosetron significantly inhibited the accelerated GI transit caused by $\mathrm{MO}\left({ }^{* *} \mathrm{P}<\right.$ 0.01 compared with the MO group $[\mathrm{n}=7]$ ).

itively or negatively. ${ }^{17} \mathrm{TRH}$ also induces release of serotonin, which results in accelerated GI transit and causes diarrhea. ${ }^{13,20}$ Similarly, MO induces 5-HT release from EC cells in vitro by way of TRPA-1, which is highly expressed in both the intestine and the stomach. ${ }^{10}$ TRPA-1 agonists are reported to have a contractile effect in isolated mouse intestine in vivo, but the effect of TRPA-1 agonists on GI motility in guinea pigs has not been verified. ${ }^{21}$ In a previous experiment in rabbits, the contractile responses of allyl isothiocyanate, which is a TRPA-1 agonist, were reduced by ramosetron. ${ }^{22}$

The $5-\mathrm{HT}_{3}$ receptors (the original 5-HT M receptor) are distributed widely in both the GI tract and the central nerve system, and result in increased intestinal secretion and alteration of peristaltic activity. ${ }^{16,23}$ In animals, 5- $\mathrm{HT}_{3} \mathrm{RAs}$ have been found to inhibit stress-induced abnormal defecation in animals. ${ }^{9}, 12$ Furthermore, $5-\mathrm{HT}_{3} \mathrm{RAs}$ already have a therapeutic use for IBS-D, and their effectiveness is well-known. $5-\mathrm{HT}_{3} \mathrm{RAs}$ have also been confirmed to have an inhibitory effect on lower GI transit, ${ }^{5,12}$ but their effects and mechanism on the upper GI tract (stomach and small intestine) have not been verified.

Previously, Doihara et $\mathrm{al}^{24}$ showed that intragastric administration of $1 \mathrm{mg} / \mathrm{kg}$ allyl isothiocyanate facilitated phasic contractions in the gastric antrum and jejunum, and that these effects were inhibited by pretreatment with ruthenium red, a TRPA-1 antagonist. However, in another study involving guinea pigs, the 
selective $5-\mathrm{HT}_{3} \mathrm{RA}$ ondansetron increased the rate of gastric emptying in vivo, ${ }^{25}$ although the precise mechanisms have not been elucidated.

Ramosetron is a potent and selective $5-\mathrm{HT}_{3} \mathrm{RA}$. Ohta et $\mathrm{al}^{26}$ have suggested that ramosetron may achieve long-lasting binding to $5-\mathrm{HT}_{3}$ receptors because ramosetron possesses the distinctive ability to maintain an active 3-dimensional chemical conformation. This drug has already proven to be effective for IBS-D in both animal and clinical studies. Recently, although Hirata et $\mathrm{al}^{27}$ showed that ramosetron significantly inhibited the delayed gastric emptying in a corticotrophin releasing factor and soybean oil-induced rat model, few studies have investigated the effects of ramosetron on altered upper GI transit. Therefore, we hypothesized that ramosetron may affect the motor function of the small bowel as well as the stomach, which was investigated by using charcoal GI transit. Aquiring the data on net effect of the gastric and small intestinal charcoal transit makes our study different from previous studies.

Our study demonstrated that ramosetron inhibits normal GI transit and that it also inhibits the accelerated GI transit induced by $5-\mathrm{HT}$, TRH and MO in guinea pigs. Along these lines, previous animal and preliminary human studies have indicated that 5- $\mathrm{HT}_{3} \mathrm{RAs}$ may facilitate activity dependent on the degree of basal tone. ${ }^{17,23} \mathrm{~A}$ few studies have also shown that $5-\mathrm{HT}_{3} \mathrm{RAs}$ accelerated delayed gastric emptying in animal models. ${ }^{28}$ On the other hand, Talley et $\mathrm{al}^{29}$ reported that ondansetron, a selective $5-\mathrm{HT}_{3} \mathrm{RA}$, did not significantly alter small intestine transit and oral to cecal transit time in healthy volunteers. Troisetron, a selective $5-\mathrm{HT}_{3} \mathrm{RA}$, has been found to either modestly increase gastric emptying or reduce it in healthy volunteers. ${ }^{30}$ The action of $5-\mathrm{HT}_{3} \mathrm{RAs}$ to modify contraction-relaxation responses would be dependent on the relative balance of excitatory-inhibitory tone. ${ }^{17,23}$ Therefore, $5-\mathrm{HT}_{3} \mathrm{RAs}$ might reduce motor activity in the presence of an abnormally increased basal activity. The transit time at lower doses of TRH and MO is actually slower compared to the control group in this study. Different doses of TRH and MO do affect GI transit. It was shown in higher doses that they accelerated GI transit. Perhaps this is due to a balance of inhibitory and excitatory tone at the neuromuscular junction. It will necessitate further investigation and more studies to explain the odd phenomena that lower doses of TRH and MO causes apparent inhibitory effect on GI transit.

In conclusion, this stuty showed that 5-HT, TRH and MO accelerated GI transit. Ramosetron, which is a $5-\mathrm{HT}_{3} \mathrm{RA}$, inhibited 5-HT, TRH and MO-induced accelerated GI transit.
Therefore, we suggest that ramosetron may be therapeutically useful for accelerated upper and lower GI transit.

\section{References}

1. Rabasseda X. Ramosetron, a 5-HT3 receptor antagonist for the control of nausea and vomiting. Drugs Today (Barc) 2002;38:75-89.

2. Steadman CJ, Talley NJ, Phillips SF, Zinsmeister AR. Selective 5-hydroxytryptamine type 3 receptor antagonism with ondansetron as treatment for diarrhea-predominant irritable bowel syndrome: a pilot study. Mayo Clin Proc 1992;67:732-738.

3. Prior A, Read NW. Reduction of rectal sensitivity and post-prandial motility by granisetron, a 5 HT3-receptor antagonist, in patients with irritable bowel syndrome. Aliment Pharmacol Ther 1993;7:175-180.

4. Shafik A, El-Sibai O, Ahmed I. Parasympathetic extrinsic reflex: role in defecation mechanism. World J Surg 2002;26:737-740; discussion 741 .

5. Hirata T, Keto Y, Nakata M, et al. Effects of serotonin 5-HT3 receptor antagonists on stress-induced colonic hyperalgesia and diarrhoea in rats: a comparative study with opioid receptor agonists, a muscarinic receptor antagonist and a synthetic polymer. Neurogastroenterol Motil 2008;20:557-565.

6. Matsueda K, Harasawa S, Hongo M, Hiwatashi N, Sasaki D. A phase II trial of the novel serotonin type 3 receptor antagonist ramosetron in Japanese male and female patients with diarrhea-predominant irritable bowel syndrome. Digestion 2008;77:225-235.

7. Matsueda K, Harasawa S, Hongo M, Hiwatashi N, Sasaki D. A randomized, double-blind, placebo-controlled clinical trial of the effectiveness of the novel serotonin type 3 receptor antagonist ramosetron in both male and female Japanese patients with diarrhea-predominant irritable bowel syndrome. Scand J Gastroenterol 2008; 43:1202-1211.

8. Taché Y, Yoneda M, Kato K, Király A, Sütö G, Kaneko H. Intracisternal thyrotropin-releasing hormone-induced vagally mediated gastric protection against ethanol lesions: central and peripheral mechanisms. J Gastroenterol Hepatol 1994;9(suppl 1):S29-S35.

9. Miyata K, Kamato T, Nishida A, et al. Role of the serotonin3 receptor in stress-induced defecation. J Pharmacol Exp Ther 1992; 261:297-303

10. Nozawa K, Kawabata-Shoda E, Doihara H, et al. TRPA1 regulates gastrointestinal motility through serotonin release from enterochromaffin cells. Proc Natl Acad Sci USA 2009;106:3408-3413.

11. Kimball ES, Wallace NH, Schneider CR, D'Andrea MR, Hornby PJ. Small intestinal cannabinoid receptor changes following a single colonic insult with oil of mustard in mice. Front Pharmacol 2010; 1:132.

12. Hirata T, Funatsu T, Keto Y, Akuzawa S, Sasamata M, Miyata K. Inhibitory effects of ramosetron, a potent and selective 5-HT3- receptor antagonist, on conditioned fear stress-induced abnormal defecation and normal defecation in rats: comparative studies with antidiarrheal and spasmolytic agents. J Pharmacol Sci 2008;106:264270.

13. Pillai NP, Bhargava HN. The effect of thyrotropin releasing hormone and morphine on gastrointestinal transit. Peptides 1984;5: 1055-1059. 
14. Nagakura Y, Kontoh A, Tokita K, Tomoi M, Shimomura K, Kadowaki M. Combined blockade of 5-HT3- and 5-HT4-serotonin receptors inhibits colonic functions in conscious rats and mice. J Pharmacol Exp Ther 1997;281:284-290.

15. Kojima R, Doihara H, Nozawa K, Kawabata-Shoda E, Yokoyama T, Ito $\mathrm{H}$. Characterization of two models of drug-induced constipation in mice and evaluation of mustard oil in these models. Pharmacology 2009;84:227-233.

16. Crowell MD. Role of serotonin in the pathophysiology of the irritable bowel syndrome. Br J Pharmacol 2004;141:1285-1293.

17. Costall B, Naylor RJ. 5-Hydroxytryptamine: new receptors and novel drugs for gastrointestinal motor disorders. Scand J Gastroenterol 1990;25:769-787.

18. Talley NJ. Review article: 5-hydroxytryptamine agonists and antagonists in the modulation of gastrointestinal motility and sensation: clinical implications. Aliment Pharmacol Ther 1992;6:273-289.

19. Ishikawa T, Yang H, Taché Y. Medullary sites of action of the TRH analogue, RX 77368, for stimulation of gastric acid secretion in the rat. Gastroenterology 1988;95:1470-1476.

20. Horita A, Carino MA. Centrally administered thyrotropin-releasing hormone (TRH) stimulates colonic transit and diarrhea production by a vagally mediated serotonergic mechanism in the rabbit. J Pharmacol Exp Ther 1982;222:367-371.

21. Doihara H, Nozawa K, Kawabata-Shoda E, Kojima R, Yokoyama T, Ito $\mathrm{H}$. TRPA1 agonists delay gastric emptying in rats through serotonergic pathways. Naunyn Schmiedebergs Arch Pharmacol 2009; 380:353-357.

22. Ito H, Hidaka K, Miyata K, Kamato T, Nishida A, Honda K. Characterization of YM060, a potent and selective 5-hydroxytryptamine3 receptor antagonist, in rabbit nodose ganglion and N1E-115 neuroblastoma cells. J Pharmacol Exp Ther 1992;263:1127-1132.

23. Farthing MJ. 5-Hydroxytryptamine and 5-hydroxytryptamine-3 receptor antagonists. Scand J Gastroenterol 1991;26(suppl 188):92100 .

24. Doihara H, Nozawa K, Kawabata-Shoda E, Kojima R, Yokoyama T, Ito $\mathrm{H}$. Molecular cloning and characterization of dog TRPA1 and AITC stimulate the gastrointestinal motility through TRPA1 in conscious dogs. Eur J Pharmacol 2009;617:124-129.

25. Gore S, Gilmore IT, Haigh CG, Brownless SM, Stockdale H, Morris AI. Colonic transit in man is slowed by ondansetron (GR38032F), a selective 5-hydroxytryptamine receptor (type 3) antagonist. Aliment Pharmacol Ther 1990;4:139-144.

26. Ohta M, Suzuki T, Ohmori J, et al. Novel 5-hydroxytryptamine (5-HT3) receptor antagonists. II. Synthesis and structure-activity relationships of 4,5,6,7-tetrahydro-1H-benzimidazole derivatives. Chem Pharm Bull (Tokyo) 1996;44:1000-1008.

27. Hirata T, Keto Y, Yamano M, Yokoyama T, Sengoku T, Seki N. Inhibitory effect of ramosetron on $\mathrm{CRF}$ - and soybean oil-induced delays in gastric emptying in rats. J Gastroenterol Hepatol 2012;27: 1505-1511.

28. Costall B, Gunning SJ, Naylor RJ, Tyers MB. The effect of GR38032F, novel 5-HT3-receptor antagonist on gastric emptying in the guinea-pig. Br J Pharmacol 1987;91:263-264.

29. Talley NJ, Phillips SF, Haddad A, et al. Effect of selective 5HT3 antagonist (GR 38032F) on small intestinal transit and release of gastrointestinal peptides. Dig Dis Sci 1989;34:1511-1515.

30. Stacher G, Bergmann H, Schneider C, et al. Effects of the 5-HT3 receptor antagonist ICS 205-930 on fat-delayed gastric emptying and antral motor activity. Br J Clin Pharmacol 1990;30:41-48. 